\begin{tabular}{ll}
\hline 論 & 説 \\
\hline
\end{tabular}

\title{
耳管機能の哀付け
}

\author{
熊沢 忠躬・本田 啓二
}

\section{Explanation of the Eustachian Tube Function}

\author{
Tadami Kumazawa and Keiji Honda
}

(Kansai Medical University)

An honorable presentation entitled "Clinical and Fundamental Studies on the Eustachian Tube" was reported at the annual meeting of Japan Society of Otolaryngology in 1980. In this presentation, the function of the Eustachian tube was discussed fundamentally and clinically, although we found that various clinical problems still remain in our practice on this tube.

The following points should be considered;

1) Are Eustachian tube problems functional or organic?

2) The location of the lesion.

3) Patency.

4) Reversibility of dysfunction.

5) Clearance function of fluid and air through the tube.

6) Relationship between this tube and peritubal lesion in the pharyngeal ostium, tympanal ostium, parotid gland and submaxillar joint.

7) Choice of therapeutic methods and evaluation of the result.

When these problems are solved, the diagnosis of the Eustachian tube function will be made clearly. Tubo-tympanoaerodynamic graphy, tympanometry, cndoscopic and electromyographic findings will be useful for this purpose. Physical and anatomical research should also be performed.

\section{はじめに}

1980年 4 月, 日本耳鼻咽喉科学会第 81 回総会に於て「耳管の基礎と臨床」と題しての宿題報告を 担当した。 てれは著者が教室をあげて 10 数年来専念して来た耳管の研究を一応まとめあげたもので あり，てれをむって，Politzer 以来 100 年の間，大方は推測の域で説明されて来た耳管機能の本態 を，基礎的な知識を借りて理論化しようと志したものである．しかしながら耳管の深遠な真理をす べて理解しえたわけではなく，未だ取り残された問題，矛盾に満ちた現象が多数に存在することは 事実である。

総会後 2 年を経た今日, 新しく開発された研究手段, 臨床検查法に助けられ, 諸外国の研究報告 
に, 我々の教室の継続研究に, 更に一歩前進した研究業績を見ることが出来る. これらの新知見, 諸見解を宿題報告に示した考察に加味して, 残された耳管機能の謎を一つ一つ解説してみたい. 勿 論根拠不充分な部分に関しては，無理な理諭づけを避けて将来の研究範囲に残しておきたい.

嘗って著者は耳管機能診断の目標として次の 7 項目の解明に主眼をおいた ${ }^{21}$.

1 ）耳管機能障害が機能的なものか，または器質的なものかの判定

2 ）耳管のどこに主病変が存在するかの判定

3 ) 病変の種類，つまり開放性加，閉塞性かの判定

4 ) 病変の程度の判定, 可逆性加非可逆性かの判定

5 ) 耳管の異物排除機能障害の判定, 换気能障害との関連

6 ) 耳管周囲（耳管咽顗口付近，耳管鼓室口付近），耳下腺一下顎関節等の疾患之の関係

7 ) 診断に基づく治療法の選択之治療効果の判定

上記の目標項目に対して明確な判定を出すととが出来れば，一応耳管機能診断の目的は達成され たといい得るであろう。1970年頃までの耳管機能診断法をむってしては，その一部を捉えることが 可能であっても，理論的にとうてい納得しうるものではなかった，その最たる理由は，客観的デー 夕を得る方法が存在しなかったからであろうかといえる，さて，耳管一鼓室気流動態法，ティンパ ノメトリー，精密な内視鏡等の発達した昨今では，ての診断に長足の進歩をとげて目的達成に近接 していると考えられる.

そこで上記目標をテーマにして逐一耳管機能の裹付けの解明を展開してみたい.

\section{機能的障害か, 器質的障害かの判定}

a ) 機能的耳管障害は存在するのか

耳管通気音の分析 ${ }^{12)}$, 耳管の解剖(5) 10) より考 えて屯, 耳管障害の $2 / 3$ は耳管咽頭口付近に病変 が存在していると推測出来る. 又臨休的に内視 鏡をむって耳管咽頭口を観察すると，耳管閉寒 症では何らかの腫脹, 浮腫, 充血, 出血などを 見るし，開放症では程度の差はあれ萎縮が見ら れる場合が殆んどである，但し剖検で耳管内病 態が確認されたわけではないので確言は出来な いが，耳管機能障害の大半は器質的なむのであ ろう。 あし耳閉塞感, 自声強調, 軽度難聴があ り, 耳管入口部の精査にもかかわらず, 病変と 思われる所見を見出すととが出来ず，しかも耳 管一鼓室気流動態図又はティンパノグラム所見 に耳管障害の異常所見を見出した場合には機能 的障害の可能性を考えるのである。乙うした場 合は耳管閉塞症で約 $30 \%$ ，耳管開放で約 $20 \%$ に 存在する.

さて機能的というと神経障害に原因するわけ であり，てれには二種類がある，つまりその第
1 は耳管筋を支配している神経問題であり，そ れは口蓋帆張筋の三叉神経第 3 枝の障害に焦点 を絞ってよい，第 2 は耳管に分布している自律 神経枝の障害で, 交感神経麻瘏と副交感神経麻 痺とが考えられる。

(1) 三叉神経麻痺と耳管機能

ここで問題になることは，三叉神経運動枝の 麻舫で耳管筋林瘏が起こり耳管機能が障害され る様な疾患が存在するかどうかということであ る。この証明のため次の様な検討を行ってみ た。まず正常人の耳管咽頭口に電極を挿入し て, 燕下時の口蓋帆張筋・挙筋の筋電図をとっ てみると, 当然のととながら両者共に明確な筋 放電が得られた（図 1 )。次に耳管機能障害例 について同様の検討をしてみると，耳管閉塞症 でも，耳管開放症でも同様に著明な筋放電が見 られたのである（図2）。こうなると，耳管機 能障害では耳管筋麻痺は存在しないといえそう である。

そこで次の段階として, 仮性球麻痺で両側の 
Tensor M.
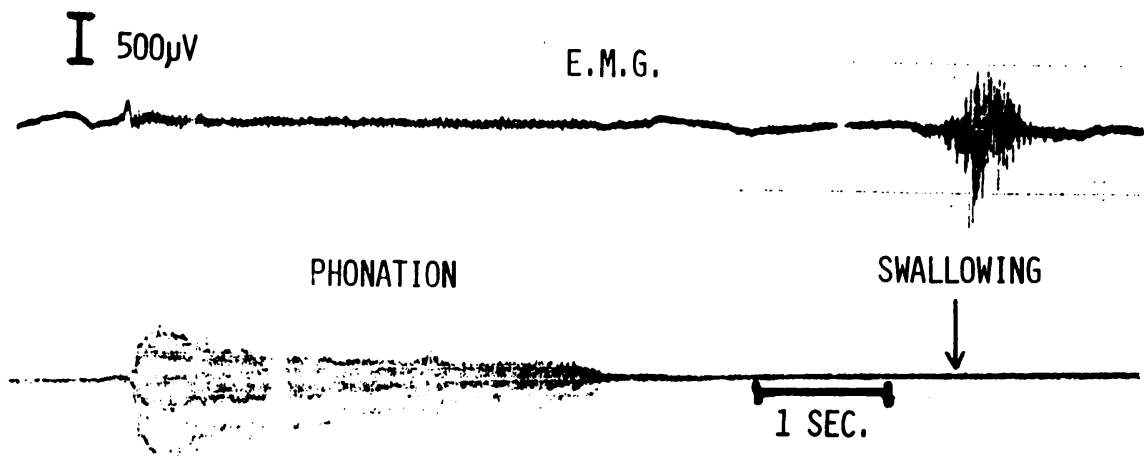

Levafor $\mathrm{M}$.

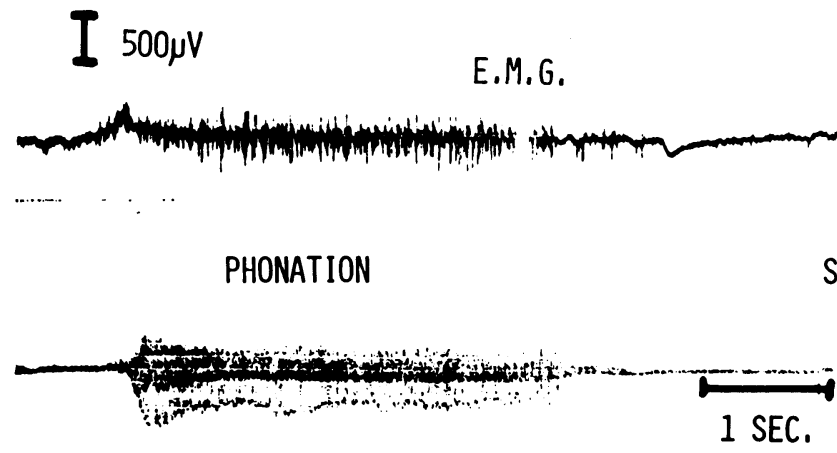

図 I 正常人の張筋, 挙筋の筋電図

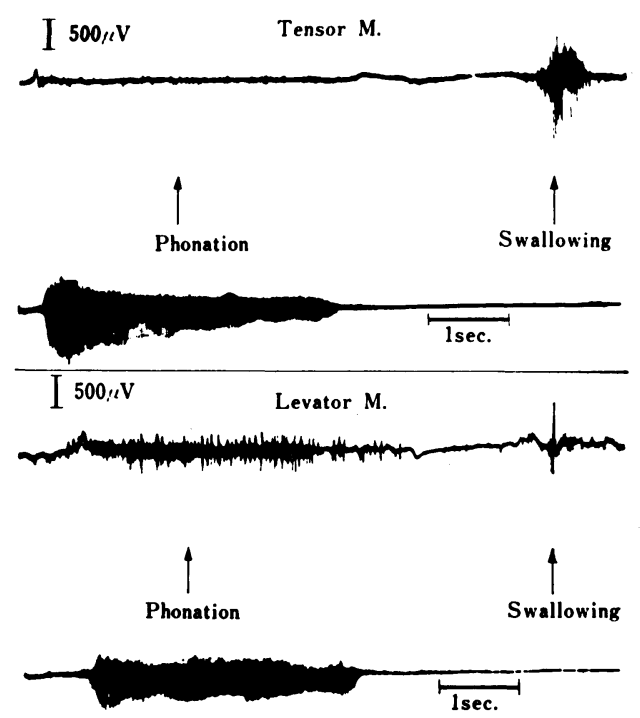

耳管决要定例における，焦下時，発声時

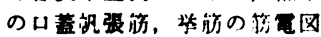
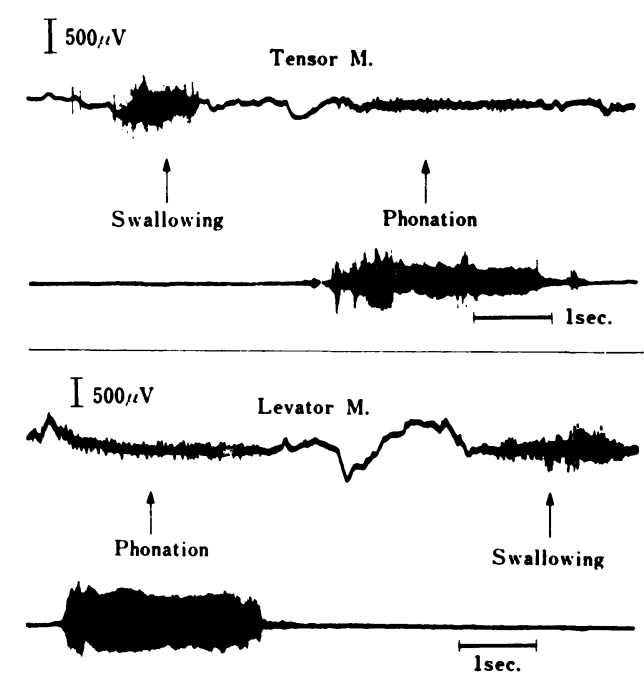

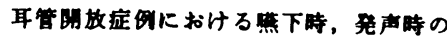
腲施，举荡策国图 


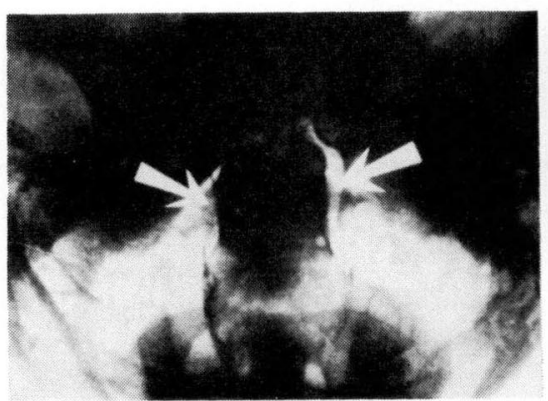

At Rest

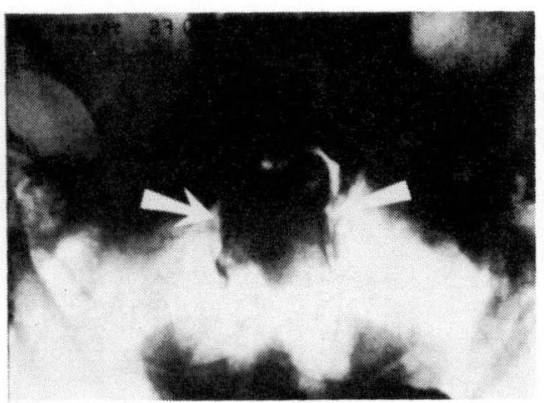

During Phonation/a/

図 3

軟口蓋麻痺のある患者の咽頭造影レ線検査を行 い（図 3 ）, 麻痺を確認したのち, 耳管機能を耳 管一鼓室気流動態法 $(\mathrm{T} \cdot \mathrm{T} \cdot \mathrm{A} \cdot \mathrm{G})$ で調べて 見ると耳管は全く正常であった（図4）.

このことは耳管に働く筋肉は張筋単独であっ て挙筋が麻痺しても耳管機能には影響を及ぼさ ないことを意味するものであり，乙の事は他の 実験によっても証明されている.

よって軟口蓋麻痺があっても張筋麻瘦はおこ らず，従って耳管機能は障害されない．乙れに よって従来よりいわれて来た筋原性の耳管障害 という概念は，張筋障害という場合にのみに限 定されてくる．乙の筋を支配している三叉神経 第 3 枝が末梢で単独で麻瘒することは，腫瘍， 膿煌の圧迫，浸潤又は口蓋裂や外傷による筋の 欠損等以外には考えられないし，又その折には それなりの他の症状が出現するであろう．次に 考え得られることは三叉神経の中枢性, 神経幹 障害に続発する場合であるが，いずれにしても その併発症状が出現するはずである．乙れを起 こす疾患としては, 卵円孔付近の trigeminal neurinoma, meningioma, osteoma や後頭蓋 窩の tumor, arachnoiditis, basilar artery aneurysm などがあげられるが現在の所その経 験を得ていないので今後の課題としている7).

三叉神経は元来知覚神経であるが，第 3 枝の みには運動線維を混ずる。乙の線維は咀嚼筋 (咬筋, 側頭筋, 内 - 外翼突筋), 顎舌筋, 顎二 腹筋前腹に分布するが，乙れらの筋には他の顔

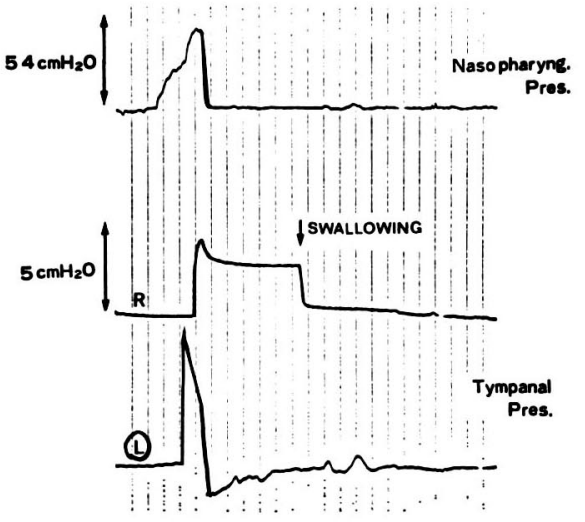

T.T.A.G.

図 4 軟口蓋麻痶の耳管機能

面神経などの運動枝も入っているので, 三叉神 経の第 3 枝が麻痺しても運動障害をおこさな い. この他に第 3 枝の単独分布する筋肉として 口蓋帆張筋, 鼓膜張筋があるので理論的には耳 管筋麻瘏，鼓膜張筋麻瘦はあり得るが，臨床的 には無視されていた。

但しチックの随伴症状として張筋の座攀が起 こり，カッカッという他覚的耳鳴を生じた症例 を経験し報告したことがある゙5. この耳鳴発現 の折に，耳管内にブジーを挿入していくと，咽 頭口より11mmの所で耳鳴は停止した。つまりて の点で座卛していたのである．この際の診断は 軟口蓋の張筋付着部（Hamulus の付近）のチ ック様痤攀と耳管内ブジー挿入とで判明出来 る. 
要するに運動神経障害由来の筋麻痺又は痤攀 による耳管機能障害は非常に少なく，むし存在 しても三叉神経障害の随伴症状を伴うから参考 になる。

(2) 自律神経障害と耳管機能

生体には生体バイオリズムが存在している. これは自律神経の周期的律動によって調整され ている. 鼻粘膜むこのリズムに従って腫脹した り消退したりして鼻の通気性が良くなったり閉 ぢたりしているが正常人では自覚されない(18). 耳管内腔の粘膜層, 粘膜下組織にも自律神経の 終末が存在する. 特に耳管咽頭口より $1 \mathrm{~cm}$ ぼ の所では粘膜層が厚くなり，血管，耳管腺が豊 富であり，その周囲に交感神経, 副交感神経終 末が網状に見られる ${ }^{15)}$. しかもこの部では粘膜 層の内方に大きな耳管軟骨が堅固な壁をつくっ ているし，粘膜層の外方は耳管腔となっている 為, 自律神経の変調は, 直ちに粘膜層の腫脹, 萎 縮となり，管腔を圧迫したり，拡大したりする (図 5 )。つまり交感神経の麻痺では耳管は閉塞

腺，血管の耳管腔に及ほす影響

B 部

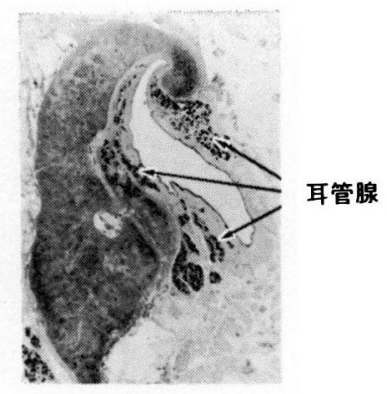

正常時

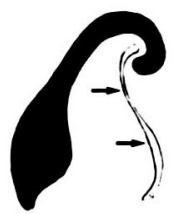

充血時

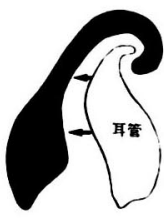

角血時
図 5
し，副交感神経の麻瘴では耳管は開放する，開 放した耳管内径の正常範囲は $0.4 \sim 0.7 \mathrm{~mm}$ であり 正常範囲を僅か $0.1 \mathrm{~mm}$ はずれても耳管機能障害 を招来する(図 6 )。正常人であ朝, 昼, 晚之生 体バイオリズムで閉塞, 開放が繰り返えされて いるのであろう。こころみに正常人の星状神経 節ブロックをして耳管を間むなく閉塞化させる し，翼口蓋神経節ブロックをして開放させるこ とが出来る（図 7 ). 又, 頭位の変換によって 屯耳管の通気性は変動する．つまりうつむくと か，あおむくと，耳管は閉じ気味となり，直立 させると耳管は開いてくる(図 8 ). だから耳管 開放症の人はうつむいて小声で話す状態をつく る. この様に頭頸部の自律神経は種々の刺激に

\section{耳管モデルによる 耳管内径と通気音との関係}

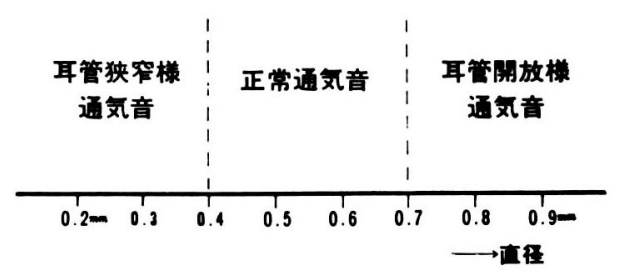

图 6
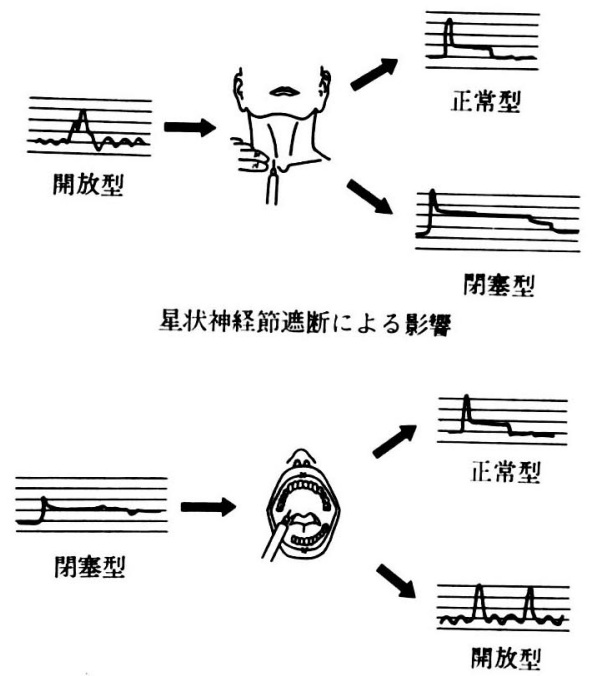

翼口蓋神経節遮断による影䐴

國 7 


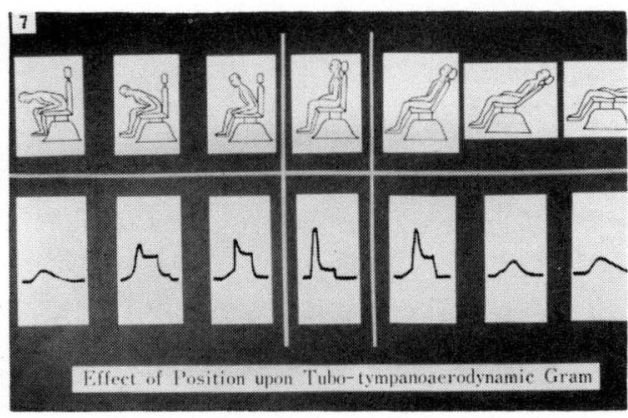

図 8

敏感に反応して変調を来しやすく，それらの多 くは頭頸部の不定愁訴として訴えられる．時に は耳鳴, 耳閉感，頭重感として屯表現されるの であって，この様な時には耳管は恐らく一時的 な機能障害がおきているであろうが，又すぐに 可逆的に正常に戻るのであろう..との症状のお きている時に内視鏡で耳管咽頭口を観察したな らば，一時的な腫脹，萎縮を見るであろう。

この様なむのをいわゆる自律神経由来の機能 的耳管障害と呼ぶことが可能であろうかと考え る.

\section{b ）器質的耳管障害}

一方, 耳管の器質的障害は機能的障害に対し て圧倒的に多数であると考えるととが出来る. そしてその変化の大部分は耳管咽頭口付近 $\mathrm{A}$ 部， $\mathrm{B}$ 部におこるであろう。一般に鼻力ゼの時 におこる耳管狭窄などはまさにその典型であ る. これらの耳管咽頭口付近の変化は近年精巧 な内視鏡によって観察可能になった。種々の器

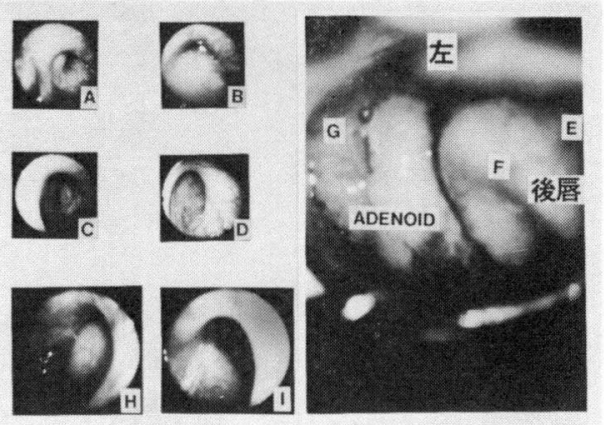

図 9

質的変化を図説すると次の如くになる（図9）.

A）慢性副鼻腔炎によく見られる後唇, 前唇 の浮腫状腫脹のため耳管口が閉塞されたもの

B ）急性副鼻腔炎においての, 充血, 発赤腫 脹のあるもの

C）慢性高度耳管狭窄症に見られる瘢痕, 癒 着のあるむの

D）乱暴な通気を行って出血のあるあの

E ）小児のアデノイドでローゼンミュラー窩 が圧迫されたもの

F ）耳管扁桃で耳管咽頭口が閉塞されたもの

G）後鼻漏で閉塞されたもの

H）急性中耳炎で咽頭口より排膿のあるあの

I ) 高度の耳管開放症で後唇, 前唇が著しく 萎縮して, 開大した耳管咽頭口より耳管内が見 えるもの

以上の様に多種多様であるので耳管疾患に際 しては上咽頭部の内視鏡的観察が強調される所 以である ${ }^{11)}$.

\section{耳管障害部位の判定}

当初は耳管を骨部，狭部，軟部にわけて，そ のどてに主病変があるかについての診断を目標 とした. しかし, 臨床的, 病理的, 解剖学的に 検討を加えているうちに，実際にはそれは大し た問題ではないととに考えが至った。つまり慢 性中耳炎では骨部より狭部にかけて主病変があ り，狭部に至ると症状が著明に出現することが 判った ${ }^{8)}$ 。というのは骨部，狭部は側頭骨の錐
体部に当たるもので，乙とには耳管周囲蜂巣が 存在する。この部は鼓室の排濃口に当たり,丁 度上管の排水口の出口に相当するので, 高度の 慢性中耳炎では，どうしてあ下鼓室蜂巣，耳管 周囲蜂巣に病巣が残存しやすい，著者らは嘗っ てこの部の骨病変を詳しく検討した折，骨壊死 を含む高度の病変を認めた。これらは当然に自 立性炎症を惹起させるものであり，乙の骨病変 
より発生した肉芽，ポリープが骨部耳管内に充 満して耳管を閉塞したり，骨増殖により耳管を 完全閉塞していた例さえある(図10)。乙の様な 症例には耳管一鼓室形成術 Tubo-Tympanobrückenplastik が適応となる 軟部耳管に病変が少く通気性の良好なととが多 (13)16)

これに反して急性中耳炎, 渗出性中耳炎の場 合，又は中耳に资症を見ない場合には骨部耳管 には著変が見られないが，軟部耳管に主病変が 存在する。この現象は何れ中耳炎に悪い影響を 与え，慢性化に導く要因となるであろう。この 際狭部には余り病変はないと考えられる．その 理由には，狭部は常時開放していることとこの 部の管腔に面した粘膜層は薄く，しかも血管，
腺が殆んど存在していないために粘膜病変のお こりにくいことがあげられる.

そこで一般に重要なのは軟部耳管であること に考えが至るのである，今，軟部耳管を耳管咽 頭门付近, 中央部, 狭部付近に分けてそのどて に主病変がおこっているかを診断することが問 題となってくる(図11).

耳管咽頭口付近については, 咽頭部に露出し ている部と，それから $1 \mathrm{~cm}$ 位耳管内部とに分け ることが出来る，我々は便宜上前者を $\mathrm{A}$ 部，後 者を $\mathrm{B}$ 部と呼ぶことにする，A部は後唇，前 唇, 挙筋隆起に囲まれた三角形の窐みで後唇の 後にはローゼンミューラー窩が存在する．とこ は常時大きく開放しているので，上咽頭の炎 症, 後鼻漏にさらされ相当高度の炎症がおき

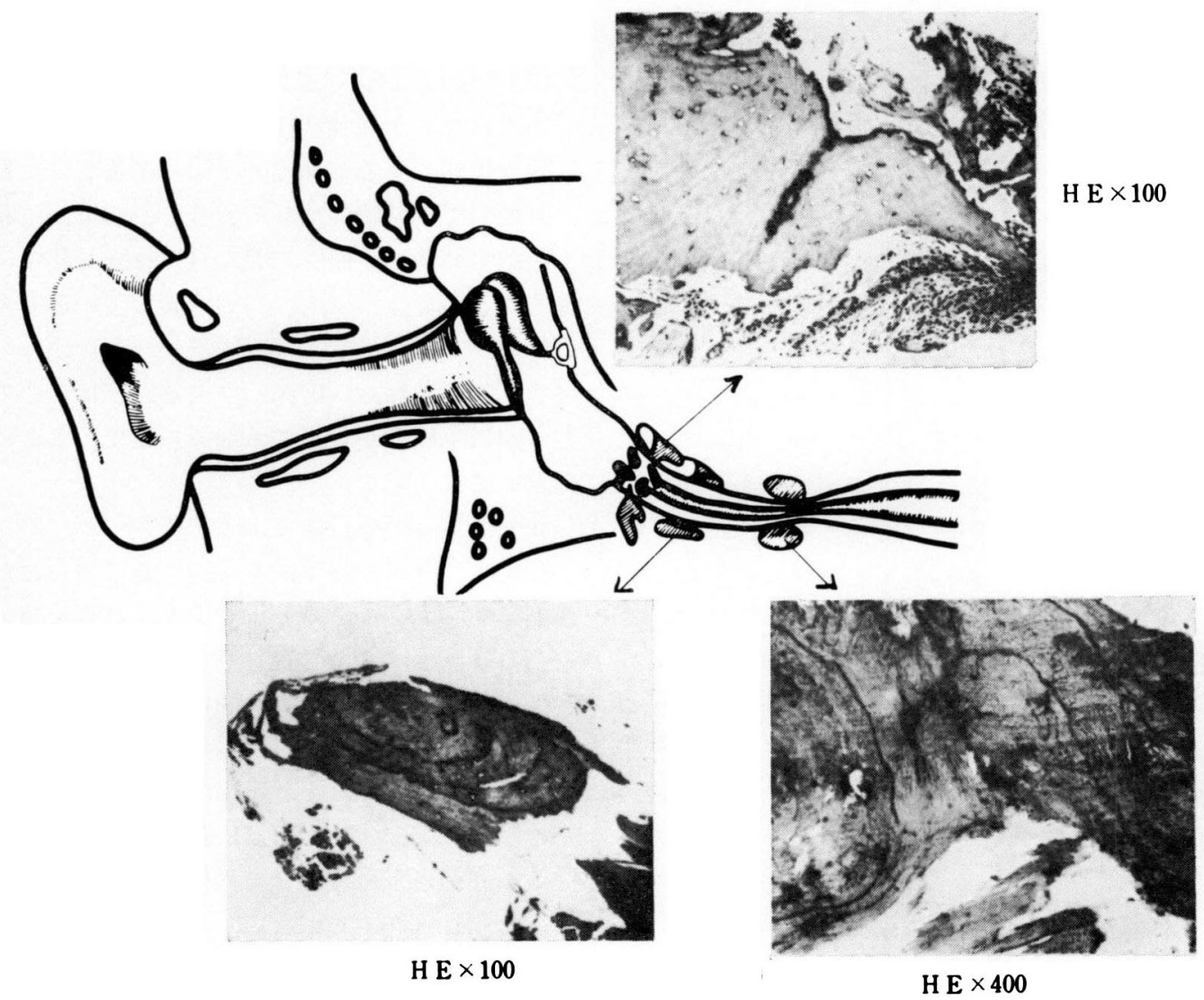

症例10 耳管鼓室口，狭部及びそれらの中間部における骨性耳管周囲部の組織像（慢性中耳炎） 


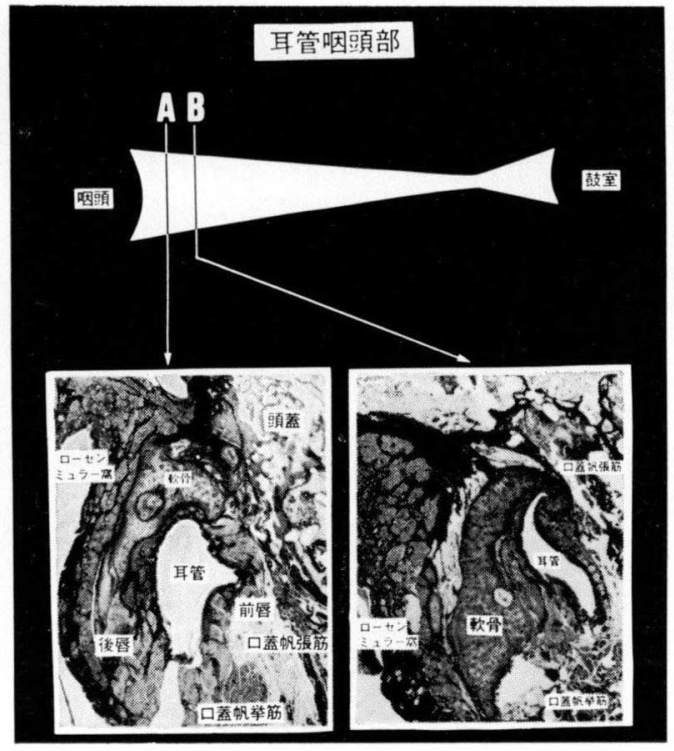

図II

ても機能的にそれほど重大な影響を与えない. 所がB 部では丁度フラスコの頸部に相当する所 であり，ここには張筋は付着していないので， 解剖学的には開放しているが，生理学的には粘 液, 唾液, 分泌液の表面張力によって膜様に口 ックされていて，耳管機能を営む上で最も重要 な場所である，又，乙の部の内側には耳管軟骨 内側板が最大になって存在しているし，その外 側の粘膜下組織もよく発達して厚くなってい る. この粘膜下組織には耳管の中で最む著明に 血管．耳管腺，リンパ管が豊富にあり，又これ らを取りまいて自律神経終末が網状に存在して いる． A 部の炎症はリンパの流れによって容易 にB部に波及するであろう。この部の炎症によ る変化 (腫脹等) は自律神経の項で前述した様 に後方に硬い軟骨板があるため直ちに耳管腔を 閉塞させる．乙の様な理由で耳管機能障害は B 部に最むおとりやすいと考えるととが可能であ る.

次に軟部耳管の中央部は張筋の付者してい る所であり, 又外側にオストマンの脂肪体が豊 富に存在して, 耳管を開大, 閉鎖させる部分で あるので機能的には大切な部分であるが, 割合
に病的変化はおこりにくいと考えられる．その 理由はこの部では高度の防禦機構が整っている からであり，それについて説明すると ${ }^{17}$

i ） B 部でロックされるため抗原，菌体が耳 管内に入りにくい.

ii ）線毛が密に存在し,その表面には mucous blanket があり, 一旦管内に入った抗原, 菌体 はこれに捕捉され, 線毛の咽頭口へ向けての運 動によってベルトコンベアの如くに耳管外に排 出される.

iii）リンパの流れが豊富に存在して，一旦抗 原, 菌体が粘膜下に侵入しても, 数分の後に咽 頭部，耳前部に流出されてしまう。

iv) IgG, IgM の抗体産生細胞が沢山存在 し，又リゾチーム等の抗炎症酵素がある.

v) 粘膜下にはサーファクタン, 弾力センイ 等があり, 粘膜が癒着するのを防禦している.

以上の如くに中央部では案外に病的変化は少 いと思われるが, 剖検で確認したわけではない.

次に狭部に至る $1 \mathrm{~cm}$ 位の範囲では張筋の付着 は欠如して, 常時開放しているし, 粘膜, 粘膜 下組織も菲薄で, 血管, 腺, 自律神経も非常に 疎であるので, 機能的, 病的意義も少いと考え られる.

さて上述した, 入口部, 中央部, 狭部の中で どの部に主病変が存在するかを診断するととは 理論的には可能である.

a ）通気音の分析法による診断

耳管カテーテル通気法を行い，その得られた 通気音をソナグラフで分析すると, 耳管狭窄の 場合にはLタイプ，L Hタイプ，L MHタイプ が得られる（図12）。実験的に耳管一鼓室模型 を作り，そのモデル耳管の各部に閉塞を作り通 気音を分析してみると，臨床的に得られたと同 一のパターン, つまり, L H, L MH タイプをつ くることが出来た，そして入口付近に狭唯を作 ると L, L H タイプが出来, 耳管全体に狭窄を 作るとL MHタイプが出現した。 このととより 臨床的通気音がL，LHタイプであれば耳管咽 頭口付近の，L MHタイプであれば耳管全体の 


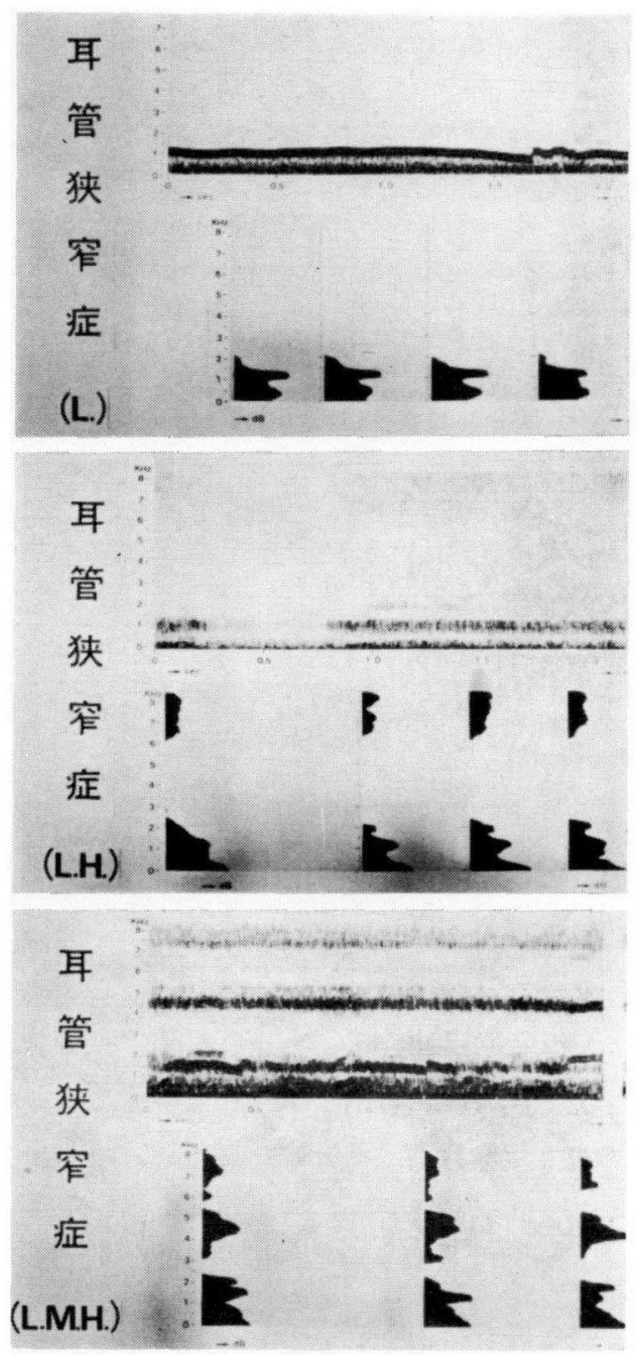

図12

狭窄があるものと推定出来る．現に渗出性中耳 炎の如く耳管全体に液が貯溜している場合には LMHタイプが出現する.

b ）鼓室内圧測定法による診断

正常耳管では嚥下をすると，耳管は開大する が開放はしない，このためティンパノメトリー で外耳道圧をしらべると，曣下に際して瞬間的 に僅かの陰圧を示す（図13）。乙の原因は耳管 咽頭口 B 部が水滴によってロックされているか らであると考えられる.

所が正常耳管でも，例えば急激に飛行機で上

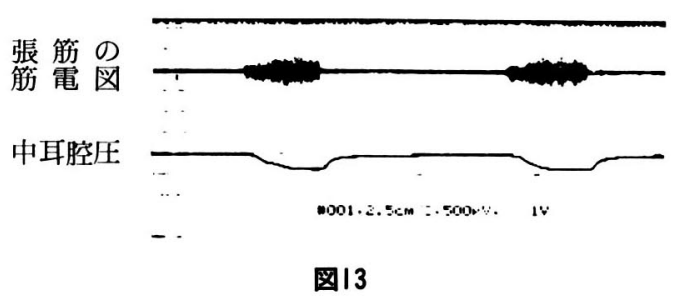

張筋の
電刺激
中耳腔圧

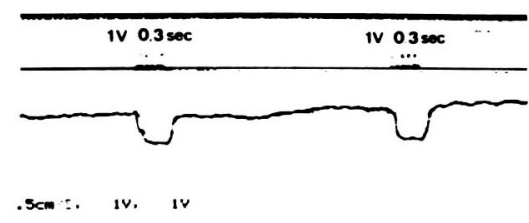

図14

昇した侍の様に, 気圧の異常によって, 鼓室内 压と外気压との間に圧差が生じた時には, 嚥下 によっててのロックがはずれ耳管は開放して， 圧バランスがとれて耳閉塞感から解放されるの である ${ }^{13)}$ 。この様な現象は実験的にも証明出来 る.つまり猿の張筋を電気刺激してその時の鼓 室内圧を測定すると, 正常耳管では張筋を電気 刺激している間中，鼓室内圧は陰圧を保つ（図

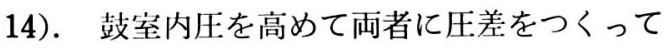
おくと，張筋の刺激によって圧は大気圧になる (図15). しかし, 耳管機能に障害があると, 前 者と異った現象がおきてくる

耳管開放症の場合

この場合も曣下によって，外耳道圧の陰圧を 示す.しかしこの陰圧形成は耳管の開大による あのではなくて上咽頭の陰圧がそのまま出現し てくるのである，その理由は，耳管咽頭口A， $\mathrm{B}$ 部の著明な萎縮のため耳管腔は開大してい て，水滴は表面張力の不足によって B部をロッ クしないからである. この理由により上咽頭圧 を深呼吸によって陽压にしても陰圧にしてもそ の変化はそのまま外耳道圧の変化として出現し てくる.

勿論この耳管開放症の場合でも, 入口が萎縮 して中央部が腫脹しているとともあるし，ての 反対に入口が腫脹し中央部の萎縮しているとと ああるであろうがこの鑑別は内視鏡によらねば 


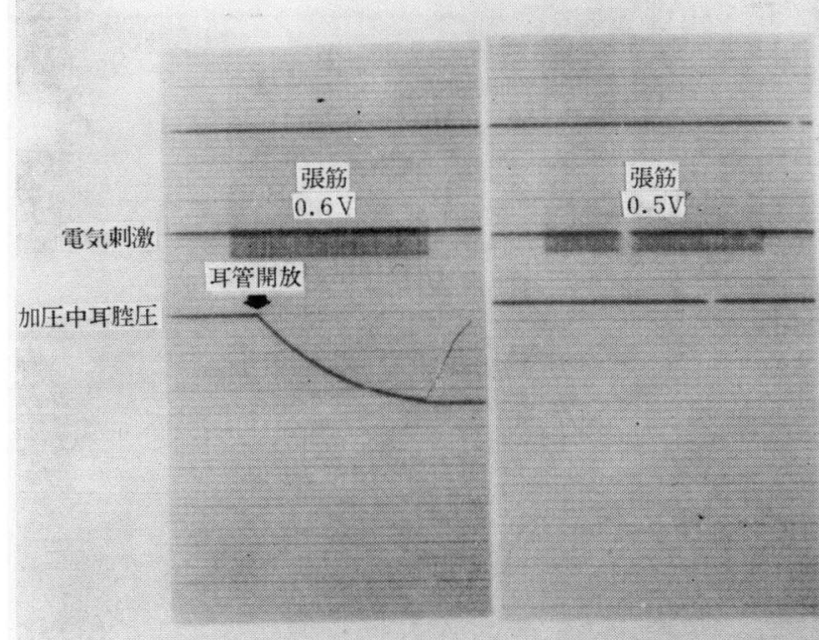

耳管開放に要する張筋の最小刺激闒値

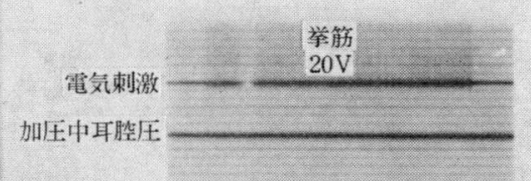

挙筋電気刺激

図 15

ならない. 又, ティンパノメトリーで正常耳管 と同様に曣下で外耳道の陰圧形成が出現し, し 加も耳管鼓室気流動体法で深呼吸による上咽頭 圧変化の外耳道圧変化に出現しないが, 嚥下す ることなく直ちに鼓室内圧の低下を示した場合 には（図16B），耳管が閉じる力を失ったもの と想像出来る.耳管の閉鎖能力は耳管中央部の 外側をとりまく Ostomann の脂肪体の受動的 な圧力によるあのであるから，こういった現象 のある時はこの脂肪体の減少を考えねばならな い. これは結核, 癌の末期や栄養失調の状態の 時におこり得るもので, それほど頻度の高いも のではないであろう。

\section{耳管開放}
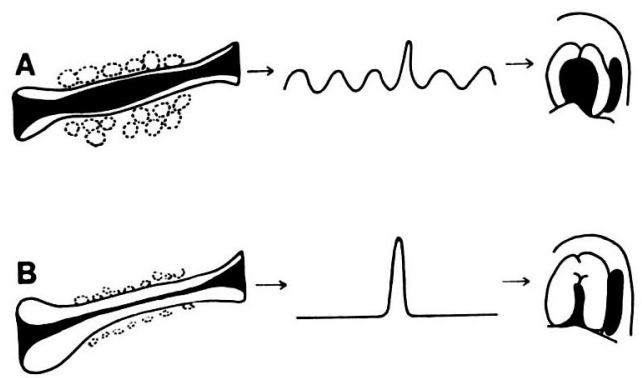

图16
耳管閉塞症の場合

耳管鼓室気流動態法によって，入りにくいタ イプ, 戻りにくいタイプの二型に分類出来るの でその夫々について検討を加えてみる.

i ）入りにくい場合 (図17A).

この原因は耳管咽頭口の腫脹閉塞によるもの と容易に考えることが出来る. 咽頭圧を $60 \mathrm{~cm}$ $\mathrm{H}_{2} \mathrm{O}$ 以上に上昇しても耳管内には気流は進入し ない場合である。しかし外正が高まるので鼓室 内压は圧迫されてなだらかねカーブを描くにす ぎない，乙の際，㫶下をして外耳道圧が陰王を つくるならば，耳管咽頭口だけの病変であり， 陰圧をつくらなりれば耳管全体の病変であると
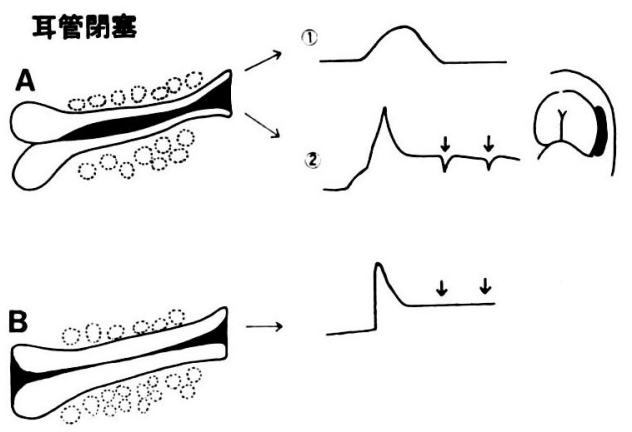

図17 
解釈出来了.

ii ) 戻りにくい場合 (図17B).

前者とは反対に，十分に空気が入り正常のパ ターンを示しているが，曣下によって鼓室内压 が下降しない点が異常である。乙れは嚥下によ り耳管が微かでも開大，開放しないことを意味 している. これには二つの理由が考えられる. その一つは耳管筋（張筋）が嚥下で働いていぬ いということがあるが，乙の時の張筋の筋電図 をとってみると活動放電があるのでての考えは 否定出来る（図 2 ).

もう一つの理由は耳管内腔が，液体などでつ まっていて，耳管は開大しても陰圧が出来ない ということを推察可能である。この様な時に は，尿素で粘張な液を除去した後に再度耳管一 鼓室気流動態法を行ってみて, 正常パターンを とるならばこの考えが肯定出来る，耳管内腔の

1）熊沢忠躬：Tubotympanobrückenplastik（高原, 熊沢）について。耳鼻臨床 $58 ： 216 \sim 224$, 1965.

2）熊沢忠躬，他：定量的耳管総合機能検査法に関す 万研究. 日耳鼻 $73: 924,1970$.

3 ）熊沢忠躬, 他：慢慢性中耳炎と耳管機能. 耳鼻臨 床 $63: 59 \sim 64,1970$

4 ）熊沢忠躬, 他：耳管開放症の検討. 耳鼻臨床 65 : 29 38, 1972.

5 ）熊沢忠躬, 他：他覚的随意的耳鳴の検討一耳鳴発 生部位とその機構の考察一. 耳鼻臨床 $66: 387$ $392,1973$.

6 ）熊沢忠躬, 他：神経耳科検査の実際（熊沢忠躬, 森本正紀監修) 医学書院 $3 \sim 4,1974$.

7) 松村浩：頭痛診断学 94頁. 金原出版, 1976.

8 ）宮崎紀美子：慢性中耳炎における骨性耳管のXX線 学的及び病理組織学的研究. 関西医大誌 $29: 159$ 〜192, 1977.

9 ) 熊沢忠躬, 他 : 耳管機能障害例の耳管筋筋電図. 耳搌 $50: 661 \sim 665,1978$.

10）熊沢忠躬，他：耳管の基礎と臨床．日耳鼻 83 ： 1416 1424, 1980 .
粘膜が全体に腫脹した場合には嚥下しても耳管 は開大しないであろうけれど，乙の際には通気 で気流が進入しにくいであろうから，T T A G はｉ）の様な入りにくいパターンをとるであろ う. 何れにしても，乙の戻りにくいタイプの原 因については，もう一つ明確な理論をつけ得な いのが現状である.

以上の様に, 耳管機能診断のための主要な二 目標について生理学的, 解剖学的根拠を基にし て考察を行い, 理論の体系化をこころみたが, 多分に推論的な点屯避けられなかった。

しかし，耳管が単なる一本の管として単純な 生理的機構と片付けられないことだけは明確で ある。

尚, 確認されていない事項については推察的 に記述し，不明な点については今後の課題とし て明記した。

\section{文 献}

11）丹家聖仁，他：内視鏡による耳管咽頭口の観察. 耳鼻臨床 $73: 204,1980$.

12）浜崎浜子：耳管通気音の音響学的研究. 耳鼻臨床 74 : 181 198, 1981.

13) Bluestone, C.D. : Recent Advances in Epidemiology, Pathogenesis, Etiology, Diagnosis and Managemnt of Otitis Media with Effusion and Certain Related Conditions. Clinical Otology Japan 9 Vol. 1, 1982.

14) Honjo, I. et al : Experimental study of the Eustachian tube function with regard its related muscles. Acta Otolaryngol (Stockh) 87 : 84, 1979.

15) Kitajiri, M. : Electron-microscopic Observation of Adrenergic Innervation in Guinea Pig Eustachian Tube. Arch Otorhinolaryngol 228 : 123 126, 1980.

16) Kumazawa $T$. et al : Aerodynamic Pattern of Eustachian Tube Dysfunction. Arch OtoRhinolary ngol. 215, 1977.

17) Lim, D. J. : Functional Morphology of the linig Membrane of the Middle Ear and 
Eustachian Tube. Ann Otol 83 : Suppl 11, 1974.

18) Stoksted, P.: Rhinomanometric measurements for determination of nasal cycle. Acta Oto- laryngol (Stockh) Suppl. I09: 159, 1953.

原稿到着：昭和57年 5 月 27 日

別刷請求先：熊沢忠躬

《570 守口市文園町 1

関西医科大学耳鼻咽喉科学教室 